\title{
The functional health status of children with cerebral palsy during the COVID-19 pandemic stay-at-home period: a parental perspective
}

\author{
Kübra Seyhan Bıyık ${ }^{\oplus}$, Cemil Özal ${ }^{\oplus}$, Merve Tunçdemir ${ }^{\oplus}$, Sefa Üneş`, \\ Kıvanç Delioğlu ${ }^{\oplus}$, Mintaze Kerem Günel ${ }^{\odot}$ \\ Department of Physiotherapy and Rehabilitation, Hacettepe University Faculty of Physical Therapy and Rehabilitation, Ankara, Turkey.
}

\begin{abstract}
Background. Coronavirus disease 2019 (COVID-19) pandemic was effective all over the world. The stay-athome period was proposed to protect against the pandemic. The aim of this study was to investigate the effects of the COVID-19 pandemic stay-at-home period on body structures and functions, activity and participation levels, and environmental factors of children with cerebral palsy (CP) from the parental perspective in Turkey.

Methods. A twenty-question survey, using the International Classification of Functioning, Disability and Health for Children and Youth set to understand the functional changes of children with CP during the stay-athome period, was sent to parents in this prospective study. Motor function levels of children were determined by the Gross Motor Function Classification System parent report. The structural equation model was used for statistical analysis.

Results. One hundred and three parents of children with CP participated. At least one of four children with CP had increased levels of anxiety (41.8\%), and increased level of a sensation of pain (34\%) and sleep problems (25.2\%). More than half of the children had increased tonus (67\%), decreased range of motion (60.2\%), decreased physical activity level (55.3\%), and decreased support level of rehabilitation services (82.6\%). During the stayat-home period activity and participation levels and environmental factors of children explained the changes of body functions as $70 \%$ and $33 \%$ (RMSEA=0.077, p<0.05).

Conclusions. This study is the first study to examine the functional health of children with CP biopsychosocially during the COVID-19 stay-at-home period. According to the parents, the functional health of children with CP was affected at different levels during the COVID-19 pandemic. Body functions may also be affected positively if physical activity level, home program and environmental supports increase.
\end{abstract}

Key words: cerebral palsy, COVID-19, function, pandemic, stay-at-home, ICF-CY.

The Coronavirus disease 2019 (COVID-19) first appeared in Wuhan, China in late 2019 and created a pandemic that was effective all over the world, especially in Europe. ${ }^{1}$ The COVID-19 outbreak was declared a "Public Health Emergency of International Concern" by the World Health Organization (WHO) on $30^{\text {th }}$ January $2020^{2}$ and a pandemic on $11^{\text {th }}$ March

$\bowtie$ Mintaze Kerem Günel

mintaze@hacettepe.edu.tr

Received 20th July 2020, revised 25th August 2020, accepted 16th October 2020.
$2020 .^{3}$ In this process, it was emphasized that people with disabilities who had a comorbidity were at a higher risk. ${ }^{4}$

Cerebral palsy $(\mathrm{CP})$ is a chronic nonprogressive neurodevelopmental problem that is caused by an injury in the immature brain; additionally, visual, hearing, sensory, perception, communication, nutrition, epilepsy may be accompanied by motor problems. ${ }^{5,6}$ The overall prevalence of $\mathrm{CP}$ is 2.1 per 1000 live births in the world but 4.4 per 1000 in Turkey.,8 Along with all these problems, the activity and participation levels of children are also restricted 
over time. They need regular physiotherapy and rehabilitation, occupational therapy and speech-language therapy in order to increase functional health status biopsychosocially. ${ }^{9}$

During the COVID-19 process, in many countries in order to reduce the risk of contamination, environments where social participation is ensured, were temporarily restricted. In Turkey, special education and rehabilitation services were interrupted between $16^{\text {th }}$ March and $15^{\text {th }}$ June 2020. Children with $\mathrm{CP}$ were not able to go outside and receive their rehabilitation service. ${ }^{10} \mathrm{WHO}$ emphasized the importance of staying at home in order to be protected from the COVID-19 pandemic but also recommended being active physically. ${ }^{11}$ Current studies suggest that activityparticipation based approaches increase functional health of children with $\mathrm{CP} .{ }^{12}$ Just the opposite, it is believed that during pandemic stay-at-home period, children with $\mathrm{CP}$ were found to be restricted to the home environment which resulted in impairment of their body structures and functions, decreased level of daily life activities and social participation.

A parent is the key member of the home program and they spend the most time with their child. In the family-centered home-based approach, the therapist acts not only as a "practitioner" but also as an "advisor " and a "follower" in order to support the family and the child in their environmental setting. ${ }^{13}$ During the COVID-19 process, the biopsychosocial health status of children and their parents, the applicability of a home program and restriction to health services were highlighted but to the best of our knowledge, no studies have been conducted that investigate which treatment models were used for children with $\mathrm{CP}$ to support their physical state during the COVID-19 process.

The International Classification of Functioning, Disability, and Health - Children and Youth version (ICF-CY) developed Cerebral Palsy core sets in order to define the health status of children with $\mathrm{CP} .{ }^{14}$ Longo et al. ${ }^{15}$ emphasized that it was crucial to adapt a biopsychosocial model in rehabilitation, strengthening the role of the immediate environment (family members and home setting) during the COVID-19 pandemic period for children's rehabilitation. However, during the COVID-19 shielding process, no studies were conducted concerning the biopsychosocial effects of environmental restrictions on the functional health status of children with $\mathrm{CP}$.

This study was carried out to investigate the effects of the COVID-19 stay-at-home period on the body functions, activity and participation status and environmental factors of children with $\mathrm{CP}$ from the parental perspectives using ICF-CY cerebral palsy core set. This study has three hypotheses: 1) during COVID-19 stayat-home process, the functional health status of children with CP would be affected biopsychosocially. 2) the number of changes in activity-participation levels and environmental factors would be related to the number of changes in body structures and functions of children during the stay-at-home period. 3) the changes in body structures and functions, activity and participation levels would differ according to the ability to walk.

\section{Material and Methods}

This prospective study was conducted during COVID-19 stay-at-home period between $16^{\text {th }}$ March - $16^{\text {th }}$ July 2020 by obtaining ethical approval from the Non-Interventional Clinical Research Ethics Committee (Project no: GO 20/420, 05.05.2020, decision no:2020/09-40) of Hacettepe University.

\section{Participants}

The study population consisted of children with $\mathrm{CP}$ and their parents who were followed at the Cerebral Palsy and Pediatric Rehabilitation Unit, Faculty of Physical Therapy and Rehabilitation in Hacettepe University, before the pandemic. Children who were diagnosed with $\mathrm{CP}$, aged between 2-18 years and those who were at home because of COVID-19 since $16^{\text {th }}$ March and who took part in therapy sessions twice 
a week before the pandemic were included in the study. Children with another diagnosis in addition to $\mathrm{CP}$ and those with missing parent contact information were excluded from the study.

Parents of children with CP were contacted by e-mail or phone and invited to participate to the study. The study was explained to the parents and informed consent forms were taken from the participants who accepted to be part of the study. The first questionnaire was sent on the $16^{\text {th }}$ May and the last acceptance date of the questionnaire was $30^{\text {th }}$ June 2020. During the survey, parents who gave missing answers were excluded from the study.

\section{Assessments}

In this study, parents of children with $\mathrm{CP}$ were asked to complete a survey about the functional health status of their children during the COVID-19 stay-at-home process. Surveys were completed using web-based video conferencing.

\section{COVID-19 Stay-at-Home Cerebral Palsy Parental Questionnaire}

This survey was created to assess the functional health status of children with $\mathrm{CP}$ from a parental perspective. Under the leadership of a thirty-year experienced specialist pediatric physiotherapist, five pediatric physiotherapists (with at least ten-year experience) developed the questionnaire by making video conferences with a focus group at three different times.

At the first meeting, four physiotherapists created a questionnaire of 31 items based on the Comprehensive ICF Core Set for Children \& Youth with Cerebral Palsy from birth to 18 age, 135 ICF categories) for the stay-at-home pandemic process and sent it to the focus group (ten pediatric physiotherapists with at least five-year experiences) for their expert opinion. At the second meeting, expert opinions were discussed. Content validity was examined by using Lawshe's Content Validity Ratio (0.80) and Content Validity Index (0.85). ${ }^{16}$ Then eleven questions that were not necessary or similar were excluded. They were sent to twelve parents to ask about their intelligibility. At the third meeting, expert opinions and parental feedbacks were combined to create a survey of 20 questions including body functions (5 questions), activity and participation (12 questions), and environmental factors (3 questions). A Likert type survey pointed as significantly decreased, decreased, not changed, increased, significantly increased was selected in order to have two-way answers and not to put psychological pressure on parents when answering. Additionally, four descriptor items were added to the survey. The final version of the standardized form of the questionnaire was prepared by two physiotherapists by using Google Form (Table I).

Gross Motor Function Classification System Family Report Questionnaire (GMFCS-FR)

GMFCS is a classification system that determines mobility and locomotion of children with $\mathrm{CP}$ at five levels according to their age ( $0-4$ years, 4-6 years, 6-12 years, 12 years and more). ${ }^{17}$ "The GMFCS family report questionnaire was modified by Morris et al. ${ }^{18}$ to define motor function level from a parental perspective. The questionnaire is available for four age bands of children and young people, specifically 2 to 4 years, 4 to 6 years, 6 to 12 years, and 12 to 18 years. The questionnaire was translated to Turkish by Kerem-Günel et al. ${ }^{19}$ and can be found at https://www.canchild.ca/.

\section{Statistical Analysis}

Statistical analyses were conducted by using IBM SPSS 26.0 software (IBM Corp, Armonk, NY, USA) and LISREL 8.71 (Scientific Software International Inc., Lincolnwood, IL, ABD). At least 100 children were planned to be included in the study since the sample size should be at least 5 times the number of questions. ${ }^{20,21}$ The variables were tested with visual (histograms/ probability plots) and analytical methods (Shapiro-Wilk's test) to check the normal distribution of variables. Demographic and clinical characteristics of the children were 
described by using mean (standard deviation) or median (minimum-maximum) for the numerical variables and by using frequency (\%) for categorical variables. The relationships between activity and participation, environmental factors and body functions were examined with a structural equation model (SEM). ${ }^{22}$ Four goodness of fit statistics were used in the analysis: Root Mean Square Error of Approximation (RMSEA $<0.08$ ), goodness of fit index $(\mathrm{GFI}<0.90)$, Chi-square and degree of freedom. Primarily, it was relied on the RMSEA of $<0.08$ to assess model fit. In addition, since chi-square is sensitive to sample size, we used the relative chi-square test (chi-square divided by degrees of freedom) with $<3$ indicating an acceptable goodness of fit. A probability level of $\mathrm{p}<0.05$ was considered statistically significant. ${ }^{23,24}$

\section{Results}

One hundred eighty-five parents, who had a child with $\mathrm{CP}$ aged between 2-18 years, were contacted by phone. Of these, 148 parents received the questionnaire via e-mail $(n=20)$ or smartphone $(n=128)$. Forty-five parents were excluded from the study because of no feedback or missing data. Finally, 103 children with CP (mean age $8 \mathrm{y} 3 \mathrm{mo}$ [4y $7 \mathrm{mo}$ ], range 2-18 years) and their parents (mean age 37 y 6 months $[5 \mathrm{y}$ 9 months], range 25-60 years) were included in the study. The flowchart of the study is shown in Figure 1.

More than half of the children were male $(\mathrm{n}=$ $58,56.3 \%$ ), and most of the respondents $(\mathrm{n}=89$, $86.4 \%$ ) were mothers. The majority of children ( $n=78,75.7 \%)$ were spastic type $\mathrm{CP}$, others were dyskinetic $(n=23,22.3 \%)$ or ataxic type $(n=2,1.9 \%)$. Almost half of the children were bilateral spastic (quadriplegia) $(n=47,45.6 \%)$. The majority of the children were classified in level V ( $n=32,31.1 \%)$ according to the GMFCSfamily report questionnaire. The clinical and demographic characteristics of the children are shown in Table I.
The duration of staying at home for the children changed between a minimum of 8 weeks and a maximum of 14 weeks. Only one child had a parent diagnosed with COVID-19. None of the children were diagnosed with COVID-19. During the stay-at-home period, most of the parents $(n=62,60.2 \%)$ continued their routine physiotherapy program that was prescribed to them by their physiotherapist before the pandemic: 24 (23.3\%) of the parents, received physiotherapy services through tele-rehabilitation, while $8(7.8 \%)$ received physiotherapist counseling services in their own home and $9(8.7 \%)$ could not reach any physiotherapy services (Table I).

For the first hypothesis: The distribution of the responses given by families to "ICF-CY Codes for Children with Cerebral Palsy during COVID-19 Pandemic Stay-at-Home Process Parental Questionnaire" are shown in Table II.

Body structures [s]: All of the children had an impairment in their brain structure (s110) and lower extremity structure (s750); and almost $75 \%$ had upper extremity impairment (s730) (Table II).

Body functions [b]: According to the parental questionnaire, the sleep duration (b134) decreased in 18 children (17.5\%) and increased in 26 children (25.2\%); the stress and anxiety levels (b152) increased in 43 children (39.8\%); the sensation level of pain (b280) increased in 35 children (33.9\%); the range of movements (b710) decreased in 63 children (61.2\%) and increased in 22 children (21.4\%). Approximately $70 \%$ of parents thought that their child's overall muscle tone (b735) value increased, while about 10\% thought their muscle tone decreased (Table II).

Activity and Participation [d]: According to the parents, $10.7 \%$ of children had a decrease in focusing attention skills and $43.7 \%$ ability to control their behavior. It is reported that six children had a decrease in hand arm use while four had an increase. During the pandemic period, approximately $20 \%$ of 

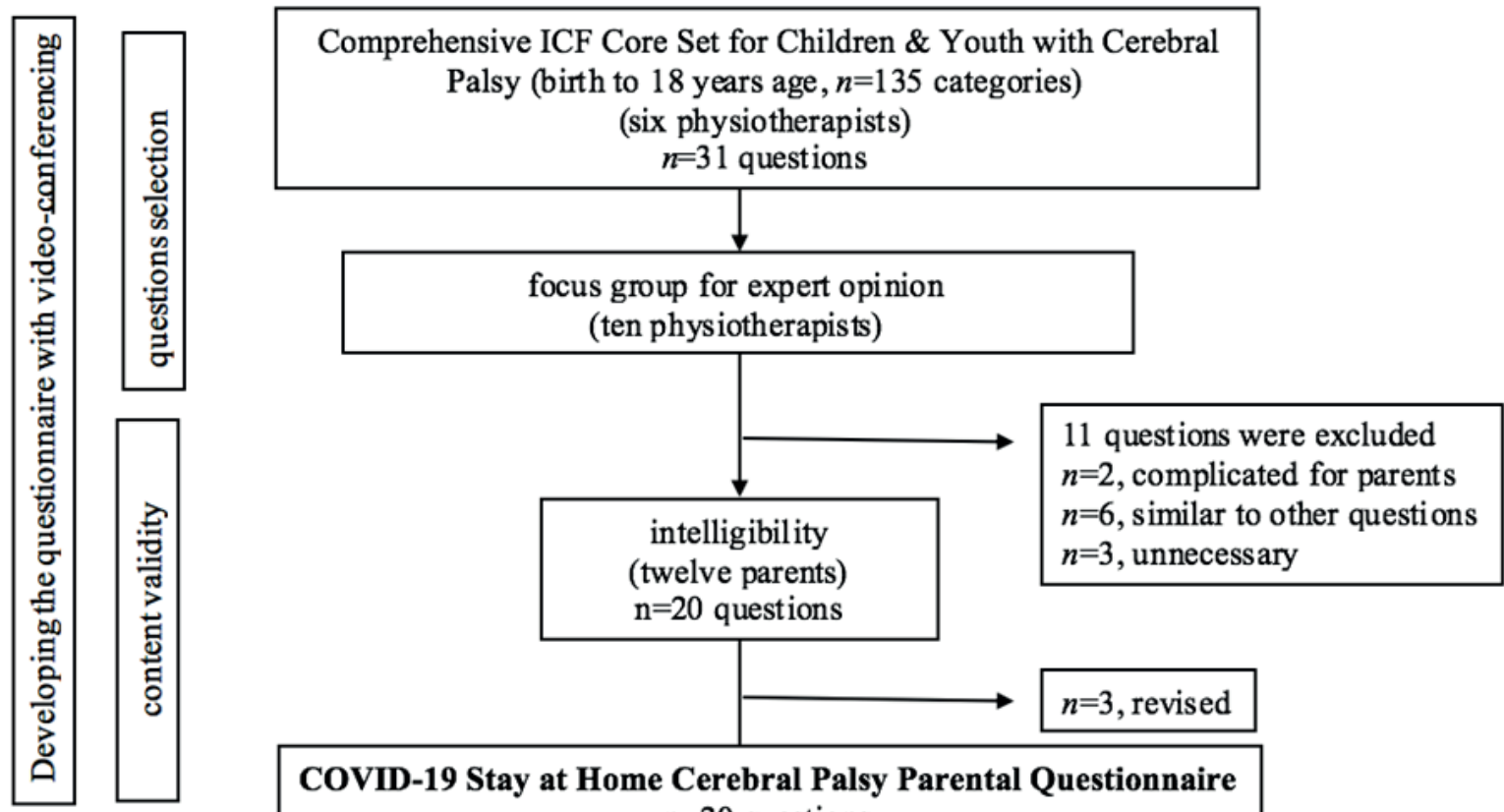

155 parents

Via smartphone

\section{COVID-19 Stay at Home Cerebral Palsy Parental Questionnaire $\mathrm{n}=20$ questions \\ 5-points Likert type}

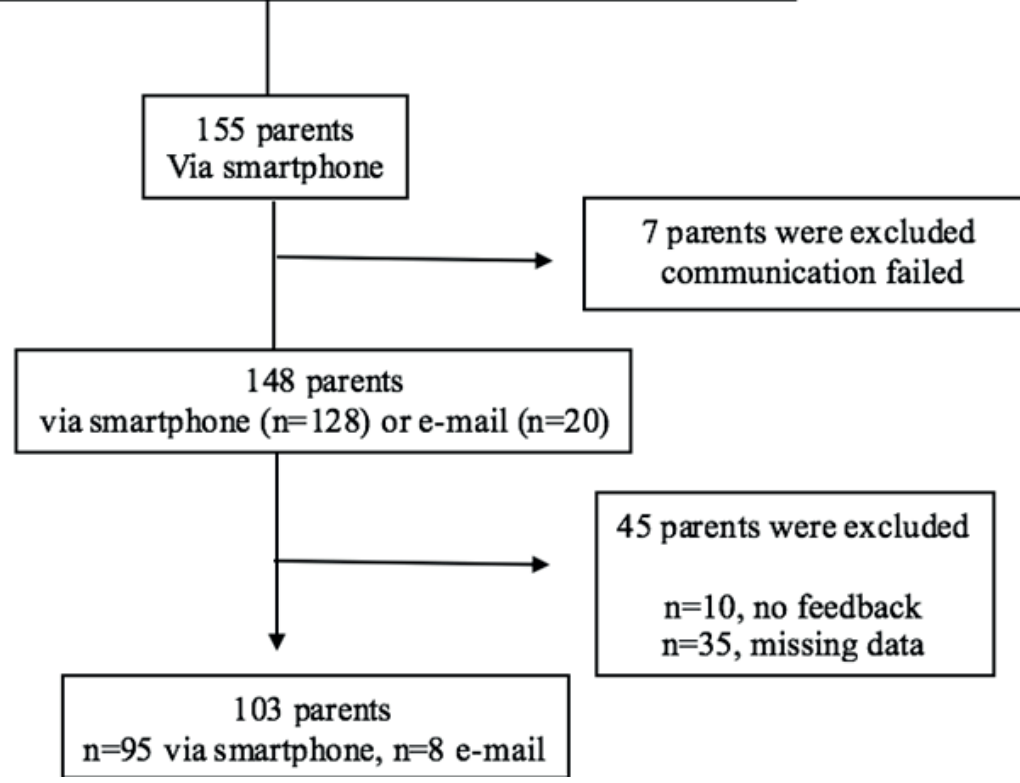

Fig. 1. Flow chart of the study.

children experienced limited walking skills. Furthermore, more than half of the children had a decrease in the level of physical activity. On the other hand, only three of the children had a decrease in their independence of self-care activities, while two of them had increased; ten children had a decrease in their independence of toileting, seven of them had a decrease in their dressing activity, and eleven children had a decrease in their eating skills. Communication skills improved in $30 \%$ of the children, but decreased in $20 \%$. The engagement level in game-based activity at home increased in more than half of the children. Although a decrease was observed in the social participation level of outdoor activity in all children. 
Table I. Demographic data of children with CP and their parents during COVID-19.

\begin{tabular}{|c|c|c|}
\hline Children with CP & $X(S D)$ & $\min -\max$ \\
\hline Mean age & $8.26(4.69)$ & $(2-18)$ \\
\hline Age distribution (GMFCS) & $\mathrm{n}$ & $\%$ \\
\hline$\leq 2$ years & 4 & 3.9 \\
\hline 2-4 years & 11 & 10.7 \\
\hline 4-6 years & 28 & 27.2 \\
\hline 6-12 years & 41 & 39.8 \\
\hline $12-18$ years & 19 & 18.4 \\
\hline Sex & $\mathrm{n}$ & $\%$ \\
\hline female & 45 & 43.6 \\
\hline male & 58 & 56.3 \\
\hline Parent & $\mathrm{X}(\mathrm{SD})$ & $\min -\max$ \\
\hline \multirow[t]{2}{*}{ mean age } & $37.66(5.99)$ & $(1-18)$ \\
\hline & $\mathrm{n}$ & $\%$ \\
\hline mother & 89 & 86.4 \\
\hline father & 14 & 13.6 \\
\hline Clinical type & $\mathrm{n}$ & $\%$ \\
\hline spastic & 78 & 75.7 \\
\hline dyskinetic & 23 & 22.3 \\
\hline ataxic & 2 & 1.9 \\
\hline Limb distribution* & $\mathrm{n}$ & $\%$ \\
\hline diplegia & 27 & 26.2 \\
\hline hemiplegia & 29 & 28.2 \\
\hline quadriplegia & 47 & 45.6 \\
\hline GMFCS parent report & $\mathrm{n}$ & $\%$ \\
\hline Level I & 14 & 13.6 \\
\hline Level II & 24 & 23.3 \\
\hline Level III & 13 & 12.6 \\
\hline Level IV & 20 & 19.4 \\
\hline Level V & 32 & 31.1 \\
\hline duration of stay-at-home & $\mathrm{n}$ & $\%$ \\
\hline 8-12 weeks & 94 & 91.2 \\
\hline$>12$ weeks & 9 & 8.8 \\
\hline having a COVID-19 diagnosis in family members & $\mathrm{n}$ & $\%$ \\
\hline yes & 1 & 0.9 \\
\hline no & 102 & 99 \\
\hline PT and rehabilitation during stay-at-home & $\mathrm{n}$ & $\%$ \\
\hline none & 9 & 8.7 \\
\hline home program & 62 & 60.2 \\
\hline tele-rehabilitation & 24 & 23.3 \\
\hline home visiting by a physical therapist & 8 & 7.8 \\
\hline
\end{tabular}

* from unit file

CP: cerebral palsy, COVID-19: coronavirus disease 2019, GMFCS: gross motor function classification system, PT:

physiotherapy, X: mean, SD: standart deviation 
Environmental Factors [e]: Orthosis and assistive device usage duration decreased in $36 \%$ of the children during the stay-at-home period, while it increased in $17 \%$. Half of the parents reported that their support levels to the home program decreased, while it increased in $20 \%$. Over $80 \%$ of parents reported that the support levels of rehabilitation/services decreased (Table II).

For the second hypothesis, the structural equation model was created to evaluate the relationships among the changes in body functions, the activity and participation levels, and environmental factors in children with $\mathrm{CP}$ during the COVID-19 stay-at-home period (Fig. 2). Walking (d450), moving around in different locations (d460) and engagement in play (d480) were selected to show the changes in activity and participation status, support levels of parents for the home program (e410) and support levels of the social services (e575) to show the changes in the environmental factors according to the model. Sensation of pain (b280), mobility of joint function (b710), muscle tone function (b735), sleep function (b134) and emotional function (b152) were chosen to demonstrate the changes in body functions. The changes in activity and participation status explained 73\% of the changes in body functions. The proposed path model showed good fit indices (the root mean square error of approximation $=0.077$, Goodness of Fit Index $=0.91$, Chi-Square $=51.15$, degree of freedom $=32, p<0.01$ ). The changes in environmental factors explained $30 \%$ of the changes in body functions (Fig. 2).

For the third hypothesis, the comparison of the questionnaire results in terms of body functions, activity and participation levels and environmental factors in children with $\mathrm{CP}$ according to their mobility status is demonstrated in Table III. It was stated that the pain and muscle tonus increased and the range of joint motion decreased in both walking and non-
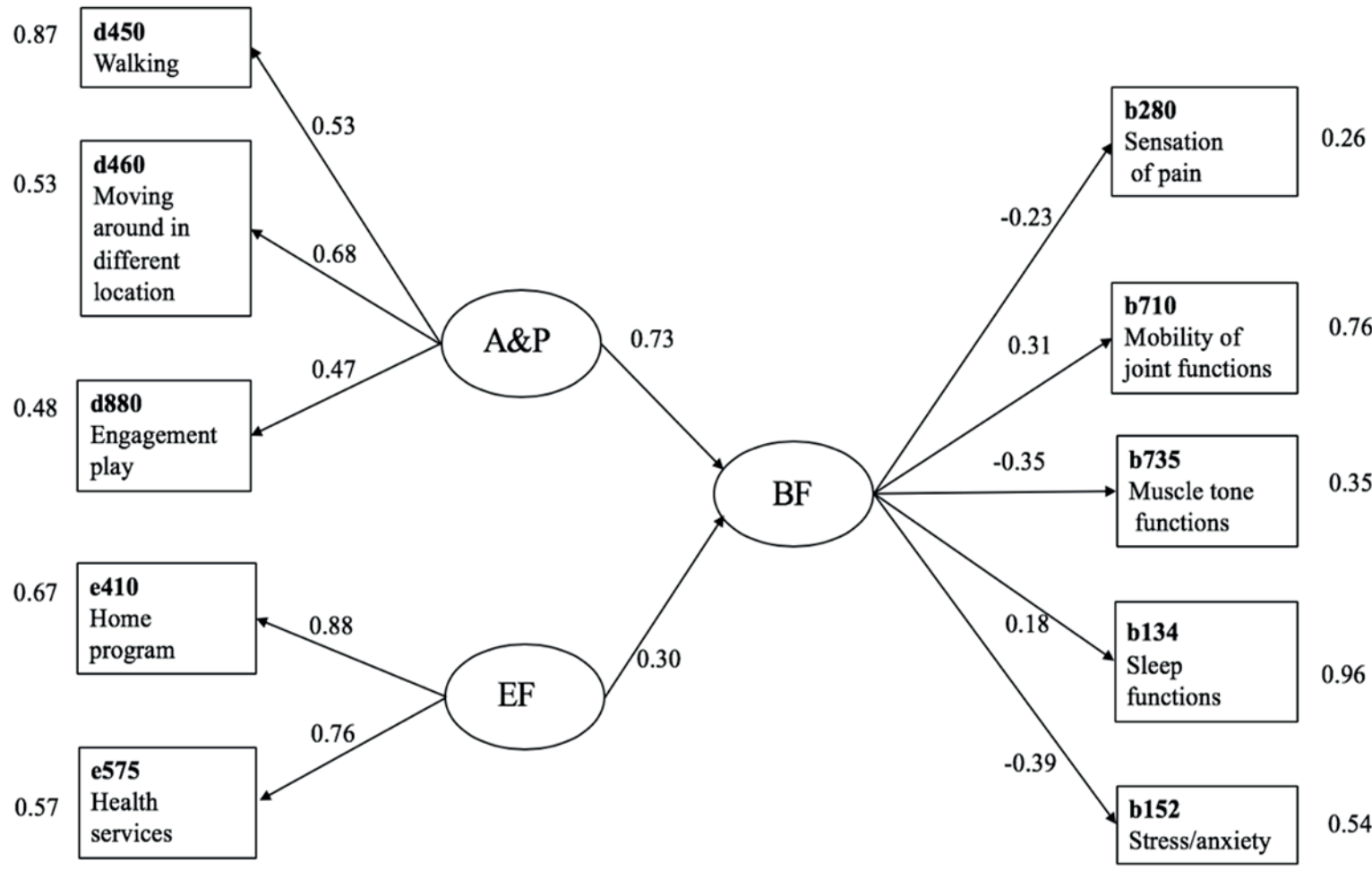

Fig. 2. According to the structural equation model, the relationship between the activity limitation and participation restriction between body functions and structures during the COVID 19 stay-at-home process (A\&P; activity and participation, EF; environmental factors, BF; body functions and structures according to ICFCY codes, Chi-Square $=51.15$, degree of freedom $=32$, Chi-Square/degree of freedom $<3$, RMSEA=0.077, $\mathrm{p}=0.01$ ). 
Table II. The percentage distribution of responses to the COVID-19 Pandemic Stay-at-Home Process Parental Questionnaire for children with CP.

\begin{tabular}{|c|c|c|c|c|c|c|c|}
\hline \multirow{2}{*}{\multicolumn{2}{|c|}{ Selected ICF-CY Codes }} & \multirow[b]{2}{*}{ During COVID-19 Pandemic Stay-at-Home, } & \multicolumn{5}{|c|}{ Qualifier (\%), n=103 } \\
\hline & & & 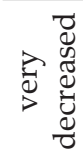 & 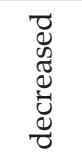 & 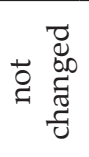 & 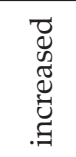 & 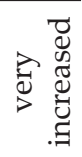 \\
\hline \multirow{5}{*}{ 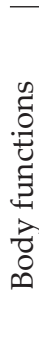 } & b134 Sleep functions & how did your child's sleep duration change? & 4.9 & 12.6 & 57.3 & 9.7 & 15.5 \\
\hline & b152 Emotional functions & $\begin{array}{l}\text { how did your child's stress/anxiety level } \\
\text { change? }\end{array}$ & 1.9 & 8.7 & 47.6 & 34 & 7.8 \\
\hline & b280 Sensation of pain & $\begin{array}{l}\text { how did your child's sensation level of pain } \\
\text { change? }\end{array}$ & - & - & 66 & 31.1 & 2.9 \\
\hline & $\begin{array}{l}\text { b710 Mobility of joint } \\
\text { functions }\end{array}$ & $\begin{array}{l}\text { how did the range of motion of your child's } \\
\text { joints change? }\end{array}$ & 6.8 & 53.4 & 17.5 & 20.4 & 1 \\
\hline & b735 Muscle tone functions & how did your child's muscle tone change? & - & 9.7 & 23.3 & 67 & - \\
\hline \multirow{12}{*}{ 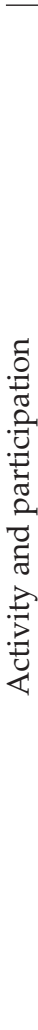 } & d160 Focusing attention & $\begin{array}{l}\text { how did your child's skills of focusing } \\
\text { attention change? }\end{array}$ & - & 10.7 & 89.3 & - & - \\
\hline & $\begin{array}{l}\text { d250 Managing one's own } \\
\text { behavior }\end{array}$ & $\begin{array}{l}\text { how was your child's skill of managing of } \\
\text { his/her behavior change? }\end{array}$ & 6.8 & 36.9 & 50.5 & 2.9 & 2.9 \\
\hline & d445 Hand and arm use & how did your child's hand-arm use change? & & 5.8 & 90.3 & 3.9 & - \\
\hline & d450 Walking & $\begin{array}{l}\text { how did your child's independence in } \\
\text { walking skill change? }\end{array}$ & - & 17.5 & 82.5 & - & - \\
\hline & $\begin{array}{l}\text { d460 Moving around in } \\
\text { different locations }\end{array}$ & $\begin{array}{l}\text { how did your child's physical activity level } \\
\text { change? }\end{array}$ & 9.7 & 45.6 & 26.2 & 12.6 & 4.9 \\
\hline & d520 Caring for body parts & $\begin{array}{l}\text { how did your child's independence in self- } \\
\text { care activity change? }\end{array}$ & - & 2.9 & 95.1 & 1.9 & - \\
\hline & d530 Toileting & $\begin{array}{l}\text { how did your child's independence in } \\
\text { toileting activity change? }\end{array}$ & - & 9.7 & 89.3 & 0.9 & - \\
\hline & d540 Dressing & $\begin{array}{l}\text { how did your child's independence in } \\
\text { dressing activity change? }\end{array}$ & - & 6.8 & 90.3 & 2.9 & - \\
\hline & d550 Eating & $\begin{array}{l}\text { how did your child's independence in eating } \\
\text { activity change? }\end{array}$ & 1.9 & 8.7 & 86.4 & 2.91 & - \\
\hline & $\begin{array}{l}\text { d710 Basic interpersonal } \\
\text { interactions }\end{array}$ & $\begin{array}{l}\text { how did your child's communication level } \\
\text { change? }\end{array}$ & 4.9 & 13.5 & 54.4 & 17.5 & 9.7 \\
\hline & d880 Engagement play & $\begin{array}{l}\text { how did your child's engagement level in } \\
\text { game-based activity at home change? }\end{array}$ & - & 6.8 & 41.7 & 17.5 & 34 \\
\hline & d920 Recreation and leisure & $\begin{array}{l}\text { how did your child's social participation } \\
\text { level of outdoor activity change? }\end{array}$ & 55.8 & 48.7 & - & - & - \\
\hline \multirow{3}{*}{ 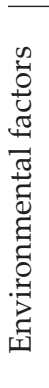 } & $\begin{array}{l}\text { e120 Products and technology } \\
\text { for personal indoor and } \\
\text { outdoor mobility and } \\
\text { transportation }\end{array}$ & $\begin{array}{l}\text { how did your child's duration of orthosis or } \\
\text { assistive devices usage change? }\end{array}$ & 9.7 & 26.2 & 47.6 & 11.6 & 4.9 \\
\hline & $\begin{array}{l}\text { e410 Individual attitudes of } \\
\text { immediate family members }\end{array}$ & $\begin{array}{l}\text { how did your support level of home exercise } \\
\text { program for your child change? }\end{array}$ & 18.4 & 31.1 & 29.1 & 18.4 & 2.9 \\
\hline & $\begin{array}{l}\text { e } 575 \text { General social support } \\
\text { services, systems and policies }\end{array}$ & $\begin{array}{l}\text { how did support levels of social services } \\
\text { (education/rehabilitation) for your child } \\
\text { change? }\end{array}$ & 21.4 & 61.2 & 7.8 & 9.7 & - \\
\hline
\end{tabular}


walking children, while the decrease in range of motion (ROM) was statistically significantly higher in children who can walk according to the reports of the parents $(p=0.043)$. The highest tonus increase was in the calf muscles, inner and backside thigh muscles (adductor muscles, hamstrings). The joint ROM limitation mostly occurred in the hip, ankle and knee, respectively. Furthermore, pain mostly occurred in the ankle, hip and knee, respectively (Fig. 3). The number of body parts with increased muscle tone in the non-walking children (GMFCS level IV and V) was statistically significantly higher than the walking children (GMFCS level I, II and III) in 69 children with CP $(p=0.043)$. The number of restricted joints in non-walking children was statistically significantly higher than in walking children $(p=0.030)$. The changes in the range of joint motion values $(p=0.043)$, hand-arm usage $(p=0.049)$, and engagement in game activities $(p=0.018)$ were statistically significant, when comparing the changes in the activity and participation levels of walking and non-walking children (Table III).
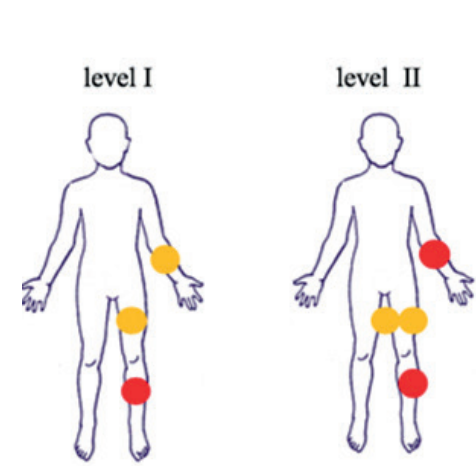

Muscle tone
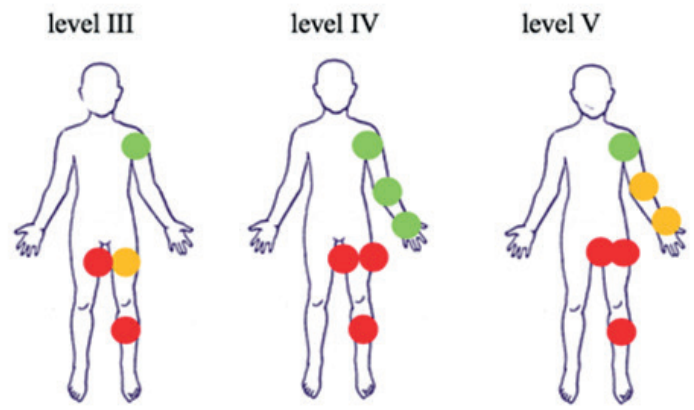

\section{Range of motion}
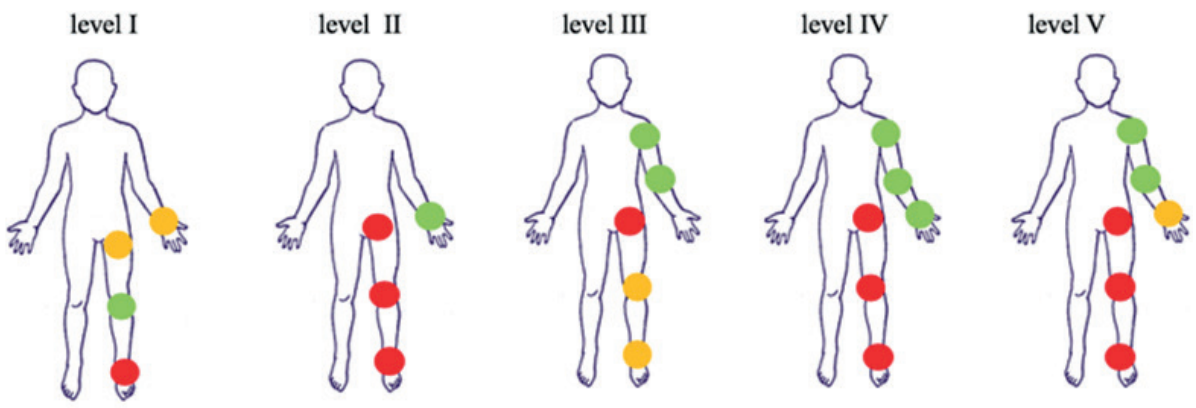

Pain
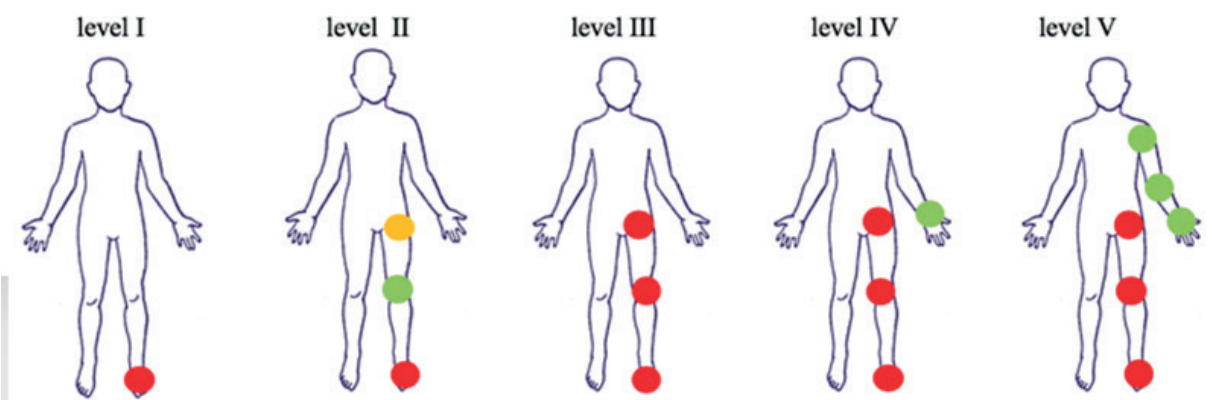

Fig. 3. Muscle tonus, range of joints motion and sensation level of pain: green ( $25 \%$ and below), yellow ( $25 \%$ $50 \%$ ) and red (50\% and above) according to GMFCS levels during COVID-19 stay-at-home period. 
Table III. Comparison of questionnaire scores in terms of body functions and structures, activity and participation and environmental factors of walking and non-walking children with cerebral palsy.

\begin{tabular}{|c|c|c|c|c|}
\hline \multirow[b]{2}{*}{$\mathrm{n}=103$} & \multicolumn{2}{|c|}{ walking non-walking } & \multirow[b]{2}{*}{ Z } & \multirow[b]{2}{*}{$\mathrm{p}$} \\
\hline & mean (SD) & mean $(\mathrm{SD})$ & & \\
\hline \multicolumn{5}{|l|}{ Body functions } \\
\hline Sleep duration & $3.24(1.04)$ & $3.13(0.9)$ & $0-.606$ & 0.544 \\
\hline Stress/anxiety level & $3.30(0.70)$ & $3.46(0.91)$ & -1.448 & 0.172 \\
\hline Sensation level of pain & $3.32(0.47)$ & $3.40(0.60)$ & $0-.381$ & 0.703 \\
\hline - number of body parts with increased pain $(n=35)$ & $3.27(0.89)$ & $3.64(0.49)$ & $0-.621$ & 0.535 \\
\hline Mobility of joints & $2.36(0.85)$ & 2.91(0.97) & -1.962 & 0.043 \\
\hline - number of body parts with decreased ROM (n=63) & $1.75(0.64)$ & $2.55(1.62)$ & -2.147 & 0.030 \\
\hline Muscle tone & $1.40(0.67)$ & $1.44(0.66)$ & $0-.303$ & 0.762 \\
\hline - number of body parts with increased muscle tone $(n=69)$ & $1.29(0.58)$ & $2.06(1.22)$ & -2.918 & 0.004 \\
\hline \multicolumn{5}{|l|}{ Activity and participation } \\
\hline Focusing attention & $2.96(0.19)$ & $2.82(0.38)$ & $0-.496$ & 0.570 \\
\hline Hand arm use & $3.04(0.34)$ & $2.62(0.26)$ & -1.875 & 0.049 \\
\hline Walking & $2.75(0.27)$ & $2.90(0.97)$ & -1.448 & 0.148 \\
\hline Physical activity & $2.46(0.90)$ & $2.67(1.07)$ & $0-.874$ & 0.382 \\
\hline Self-care & $3.02(0.31)$ & $3(0)$ & $0-.461$ & 0.645 \\
\hline Toileting & $2.90(0.34)$ & $2.92(0.29)$ & $0-.259$ & 0.796 \\
\hline Dressing & $2.60(0.36)$ & $3.01(0.24)$ & 0.796 & 0.042 \\
\hline Eating & $2.96(0.19)$ & $2.88(0.47)$ & $0-.487$ & 0.626 \\
\hline Communication & $3.22(1.03)$ & $3.05(0.84)$ & $0-.496$ & 0.620 \\
\hline Playing & $4(0.96)$ & $3.55(0.97)$ & -2.359 & 0.018 \\
\hline Social participation & $1.56(0.59)$ & $1.44(0.509)$ & -1.276 & 0.202 \\
\hline \multicolumn{5}{|l|}{ Environmental factors } \\
\hline Orthosis and assistive devices & $2.76(1.02)$ & $2.76(0.89)$ & $0-.456$ & 0.649 \\
\hline Exercise program & $2.18(1.02)$ & $2.75(1.29)$ & $0-.813$ & 0.416 \\
\hline Supports of health/education services & $226(0.95)$ & $2.26(0.96)$ & -1.120 & 0.263 \\
\hline
\end{tabular}

Mann Whitney U test, $\mathrm{p}<0.05$

GMFCS: gross motor function classification system, ROM: range of motion, SD: standard deviation

\section{Discussion}

To the best of our knowledge, this study is the first study in the literature to investigate the functional health status of children with $\mathrm{CP}$ during the COVID-19 stay-at-home period. The questionnaire developed to assess the changes in body functions, activity and participation levels and environmental factors of children with $\mathrm{CP}$ was asked online to parents and it was found that the functional health status of children with $\mathrm{CP}$ was affected at various degrees. According to the parental reports, at least one of every four children had increased stress/anxiety levels, sensation level of pain, and sleep problems. More than half of the children had increased muscle tonus; whereas range of joint motion, duration of orthosis and assistive device usage, indoor and outdoor activityparticipation level were found to be decreased. During the stay-at-home period, support levels of parents to the home program and support levels of rehabilitation services were found to be declined. Furthermore, limitations in activity and participation levels and changes in parental or rehabilitation service supports affected the changes in body functions of children. Accordingly, the walking ability of the severely affected children were found to be mostly impaired during the stay-at-home period. 
The life habits of the children with $\mathrm{CP}$ had changed due to environmental constraints imposed under health policies. In this study, we found that the outdoor activities of all children were restricted. While most of the children continued previous home exercise programs, a quarter of them benefited from telerehabilitation programs by using smartphone applications, videoconferences and/or videobased telephone consultation. Goldschmidt et al. ${ }^{25}$ stated that technology-based approaches should be used to provide social, emotional and functional wellbeing for children in the COVID-19 period. The use of tele-rehabilitation provides benefits such as better clinical outcomes, greater involvement and completion of interventions and greater service satisfaction compared to other interventions. ${ }^{26,27}$ In the current study, there were positive changes or no change in the daily living activities of the children participating in tele-rehabilitation. On the other hand, nine children were not treated in any way, and their parents responded negatively.

As a result of prolonged physical inactivity in children with $\mathrm{CP}$, morphological changes in muscles such as non-use atrophy may lead to impairment of muscles. Additionally, intramuscular protein synthesis, muscle fiber cross-sectional area and muscle mass decrease over time as a result of immobilization. ${ }^{28}$ Lack of activity and participation during the COVID-19 period may cause problems in body structures and functions. Deterioration of bone structures, muscle weakness, muscle atrophy, muscle shortness and then contractures, also by developing joint limitation could lead to restriction or limitation of home activities if sufficient functional activity is not supported. ${ }^{29}$ In this study, changes in activity and participation were seen to be related to the changes in body functions by $73 \%$. Parallel to these findings, WHO emphasized the importance of physical activity during the pandemic period. Children who had an increase in indoor activities showed a decrease in muscle tonus, pain and stress levels, whereas the ROM and duration of sleep increased. In addition, it was observed that the communication skills of one of every four children increased, even though indoor activities of children decreased and body functions were affected negatively. Especially, during the stay-at-home period, it might be helpful to advise parents about agedependent home-based activities for their children for being physically active.

Regarding the ICF-CY, the current conceptual rehabilitation models which covered participation in different life settings such as the home, school, and community participation became more obvious in accordance with the biopsychosocial approach. Recently, Novak et al. $^{30}$ in their systematic review stated that home program, play and activity-based interventions were found to be beneficial for functional health status. The emerging focus on the environment in therapy intervention is consistent with current evidence. Furthermore, a restricted environment may also negatively affect motor learning in children with $\mathrm{CP} .{ }^{31}$ Home arrangements, family support on exercise programs, social manners, access to health care affect activity and participation levels. ${ }^{32}$ Espi Tella at al..$^{33}$ showed that social support of parents or friends and geographical conditions were the most common facilitators while insufficient physical environment, problems about transportation, politics, negative attitudes and inadequate support of service providers were the most common barriers of participation of children with CP. Longo et al. ${ }^{15}$ reviewed the importance of home programs and the support of the immediate environment (parent and home environment) in children's rehabilitation in low- and middle-income countries during the COVID stay-at-home period. In this study, changes in supports level of parents to home programs and support level of rehabilitation services explained the changes in muscle tonus, sensation level of pain, joint movements, stress/ anxiety level and duration of sleep by thirty percent. Additionally, environmental factors were found to be a predictor on body function impairment of children with $\mathrm{CP}$ during the 
stay-at-home period. It is thought that homebased arrangements to reduce environmental barriers and increase of home program support to parents may have had positive improvements on body functions of children. Furthermore, rehabilitation professionals can use online transdisciplinary consultancy services to educate parents about the home organizations, coping with stress and homebased managements.

Palisano et al. ${ }^{34}$ emphasized that in ambulatory or non-ambulatory children with $\mathrm{CP}$, indoor and outdoor activity preferences and performance of chosen activities differ from each other. According to the current study, children with different mobility levels were affected differently from the pandemic period. According to parents, during the stay-at-home period, although indoor play activities of walking children increased, pain of the ankle joint increased and movements were seen to be decreased. In non-walking children, especially around the hip and ankle, all upper and lower extremities were affected in terms of muscle tonus, joint movement and pain.

Considering the pandemic stay-at-home period, which is likely to reoccur in the future, there may be a need for video-based technologic assessments and therapy programs that may offer indoor activities alternatively according to gross motor function levels of children with $\mathrm{CP}$.

None of the children in the current study were infected with COVID-19. Only one of the mothers had contracted the virus. She reported that it had affected her child both physically and psychologically. Biopsychosocial changes in parents may also be related to the decrease in children's functional health and home program support.

This study has several limitations. The study was evaluated only in terms of physiotherapy and rehabilitation, and the content validity of the questionnaire consisted of physiotherapists and parents. Although we contacted at least five children with $\mathrm{CP}$ for each item, the number of samples to compare multiple groups according to GMFCS levels could not be reached. We were unable to find a valid and reliable home-based assessment scale to evaluate children's muscle tonus, joint movements, stress and sleep patterns in the home environment. The heterogeneous wide age distribution of children with $\mathrm{CP}$ and no detailed structural equation model about accompanying problems affecting functionality such as seizures, hearing, vision, emotional and behavioral problems were the other limitations of this study.

Future studies should investigate the effect of changes of the environment, activity and participation levels on functional health in all the children with neurodevelopmental problems who had to experience the stay-athome period for different reasons according to different age range such as preschooler, schooler or adolescent. In addition, follow-ups should be evaluated after the restriction period. Considering that this lock-down process can be repeated, health politics should give priority to family-centered home-based tele-rehabilitation applications on health services. An increase of family stress/anxiety level and decrease in physical activity may affect the functional health status of children. In the future studies, there is need for biopsychosocial practices which evaluate the family under the transdisciplinary perspective including different disciplines like psychologist, occupational therapist and speech-language therapist mostly in the sample group. It should also be examined how functional health status has changed in families diagnosed with COVID-19 or in children with CP. All parents stated that they were affected emotionally and that their stress levels increased during the stay-at-home period when accepting to participate in the study. The increased level of depression or anxiety in parents should be evaluated with a short Likert type scale in future studies. In addition, the communication function levels of children may be classified according to Communication Function Classification System. The state of pain and anxiety should be assessed by asking the 
children with appropriate age, communication level and cognitive status in future studies.

This study is the first study to examine the functional health of children with $\mathrm{CP}$ biopsychosocially during the COVID-19 stayat-home period. According to parent reports, during the lockdown period, body structures and function, activity and participation levels and environmental factors of children with $\mathrm{CP}$ were affected. Changes in life routines, physical activity and participation level affect changes of sensation level of pain, muscle tonus, joint movements, stress and sleep duration of children with $\mathrm{CP}$. During the pandemic period, changes in support levels of parent and rehabilitation are related to changes in body functions. There is always a possibility that the pandemic will repeated itself, so in order to have no effect on the functional health of children with $\mathrm{CP}$, there is an emergent need for home-based assessments concerning body functions and home-based therapy studies.

\section{Acknowledgements}

We would like to thank all the experts in the focus group and parents for participating our study.

\section{REFERENCES}

1. Mavragani A. Tracking COVID-19 in Europe: infodemiology approach. JMIR Public Health Surveill 2020; 6: e18941.

2. World Health Organization. 2019-nCoV outbreak is an emergency of international concern. Available at: https://www.euro.who.int/en/health-topics/healthemergencies/international-health-regulations/news/ news/2020/2/2019-ncov-outbreak-is-an-emergencyof-international-concern. (Accessed on June 19, 2020).

3. World Health Organization. WHO DirectorGeneral's opening remarks at the media briefing on COVID-19 - 29 June 2020. Available at: https://www. who.int/director-general/speeches/detail/whodirector-general-s-opening-remarks-at-the-mediabriefing-on-covid-19---29-june-2020. (Accessed on July 25, 2020).
4. World Health Organization. Disability considerations during the COVID-19 outbreak. Available at: https://www.who.int/publications/i/ item/WHO-2019-nCoV-Disability-2020-1. (Accessed on July 25,2020 ).

5. Blair E, Cans C. The definition of cerebral palsy. In Panteliadis CP(ed). Cerebral Palsy: A Multidisciplinary Approach. (3rd ed). Switzerland: Springer International Publishing AG, 2018: 13-17.

6. Rosenbaum P, Paneth N, Leviton A, et al. A report: the definition and classification of cerebral palsy April 2006. Dev Med Child Neurol Suppl 2007; 109: 8-14.

7. Oskoui M, Coutinho F, Dykeman J, Jetté N, Pringsheim T. An update on the prevalence of cerebral palsy: a systematic review and metaanalysis. Dev Med Child Neurol 2013; 55: 509-519.

8. Serdaroğlu A, Cansu A, Ozkan S, Tezcan S. Prevalence of cerebral palsy in Turkish children between the ages of 2 and 16 years. Dev Med Child Neurol 2006; 48: 413-416.

9. McCoy SW, Palisano R, Avery L, et al. Physical, occupational, and speech therapy for children with cerebral palsy. Dev Med Child Neurol 2020; 62: 140146.

10. Cumhurbaşkanı Sözcüsü Kalın: Korona virüsle mücadele sürecini, el birliğiyle rehavete ve paniğe kapilmadan atlatma kabiliyetine sahibiz. Available at: https://www.tccb.gov.tr/haberler/410/117021/ cumhurbaskanligi-sozcusu-kalin-korona-virusle-mucadele-surecini-el-birligiyle-rehavete-vepanige-kapilmadan-atlatma-kabiliyetine-sahibiz- . (Accessed on July 10, 2020).

11. World Health Organization. Connecting the world to combat coronavirus. Available at: https://www. who.int/campaigns/connecting-the-world-tocombat-coronavirus. (Accessed on June 25, 2020).

12. Reedman S, Boyd RN, Sakzewski L. The efficacy of interventions to increase physical activity participation of children with cerebral palsy: a systematic review and meta-analysis. Dev Med Child Neurol 2017; 59: 1011-1018.

13. Larsson I, Miller M, Liljedahl K, Gard G. Physiotherapists' experiences of physiotherapy interventions in scientific physiotherapy publications focusing on interventions for children with cerebral palsy: a qualitative phenomenographic approach. BMC Pediatr 2012; 12: 90.

14. Schiariti V, Selb M, Cieza A, O'Donnell M. International classification of functioning, disability and health core sets for children and youth with cerebral palsy: a consensus meeting. Dev Med Child Neurol 2015; 57: 149-158. 
15. Longo E, de Campos AC, Schiariti V. COVID-19 pandemic: is this a good time for implementation of home programs for children's rehabilitation in lowand middle-income countries? Phys Occup Ther Pediatr 2020; 40: 361-364.

16. Ayre C, Scally AJ. Critical values for Lawshe's content validity ratio: revisiting the original methods of calculation. Meas Eval Couns Dev 2014; 47: 79-86.

17. Palisano R, Rosenbaum P, Walter S, Russell D, Wood E, Galuppi B. Development and reliability of a system to classify gross motor function in children with cerebral palsy. Dev Med Child Neurol 1997; 39: 214-223.

18. Morris C, Bartlett D. Gross motor function classification system: impact and utility. Dev Med Child Neurol 2004; 46: 60-65.

19. Kerem-Günel M, İncesu-Oral E. GMFCS Family and Self Report Questionnaire (Turkish) Centre for Childhood Disability Research, 2019. Available at: https://canchild.ca/system/tenon/assets/ attachments/000/002/644/original/GMFCS-_FR_ Turkish_form_Mintaze_Kerem_G\%C3\%BCnel_14_ March_2019_FINAL.pdf. (Accessed on June 18, 2020).

20. Tabachnick BG, Fidell LS. Using Multivariate Statistics. (5th ed) Boston: Pearson/Allyn and Bacon, 2007.

21. Preacher KJ, MacCallum RC. Exploratory factor analysis in behavior genetics research: factor recovery with small sample sizes. Behav Genet 2002; 32: 153-161.

22. Schumacker RE, Lomax RG. A Beginner's Guide to Structural Equation Modeling. (3rd ed) New York: Routledge, Taylor and Francis Group, 2010.

23. Kelloway EK. Using LISREL for Structural Equation Modeling: A Researcher's Guide. (1st ed) Thousand Oaks: Sage Publications, 1998.

24. Hayduk LA. Structural Equation Modeling with LISREL: Essentials and Advances. Baltimore and London: Johns Hopkins University Press, 1987.
25. Goldschmidt K. The COVID-19 pandemic: technology use to support the wellbeing of children. J Pediatr Nurs 2020; 53: 88-90.

26. Kairy D, Lehoux P, Vincent C, Visintin M. A systematic review of clinical outcomes, clinical process, healthcare utilization and costs associated with telerehabilitation. Disabil Rehabil 2009; 31: 427447.

27. Edirippulige S, Reyno J, Armfield NR, Bambling M, Lloyd O, McNevin E. Availability, spatial accessibility, utilisation and the role of telehealth for multi-disciplinary paediatric cerebral palsy services in Queensland. J Telemed Telecare 2016; 22: 391-396.

28. Verschuren O, Smorenburg ARP, Luiking Y, Bell K, Barber L, Peterson MD. Determinants of muscle preservation in individuals with cerebral palsy across the lifespan: a narrative review of the literature. J Cachexia Sarcopenia Muscle 2018; 9: 453464.

29. Barrett RS, Lichtwark GA. Gross muscle morphology and structure in spastic cerebral palsy: a systematic review. Dev Med Child Neurol 2010; 52: 794-804.

30. Novak I, Morgan C, Fahey M, et al. State of the evidence traffic lights 2019: systematic review of interventions for preventing and treating children with cerebral palsy. Curr Neurol Neurosci Rep 2020; 20: 13 .

31. Anaby D, Korner-Bitensky N, Steven E, et al. Current rehabilitation practices for children with cerebral palsy: focus and gaps. Phys Occup Ther Pediatr 2017; 37: 1-15.

32. Albrecht EC, Khetani MA. Environmental impact on young children's participation in home-based activities. Dev Med Child Neurol 2017; 59: 388-394.

33. Espín-Tello SM, Colver A; SPARCLE Group. How available to European children and young people with cerebral palsy are features of their environment that they need? Res Dev Disabil 2017; 71: 1-10.

34. Palisano RJ, Tieman BL, Walter SD, et al. Effect of environmental setting on mobility methods of children with cerebral palsy. Dev Med Child Neurol 2003; 45: 113-120. 